\title{
The Sanctity of Emmaus Pilgrimage Heritage Site: The Case of Abbot Francis Pfanner
}

\author{
Samkelisiwe Nkwanyana \\ Department of Recreation and Tourism \\ University of Zululand, Private Bag X1001 \\ KwaDlangezwa 3886, South Africa \\ E-mail: nkwanyanaS@unizulu.ac.za \\ ORCID: 00-0000-02188-48152 \\ Fr. Thamsanqa Njiyela CMM \\ The Congregation of the Missionaries of Mariannhill \\ Email: thamsanqanjiyela@gmail.com \\ Doi: https://doi.org/10.46222/pharosjot.102.024
}

\begin{abstract}
The focus of this paper is to describe the establishment and origins of Emmaus pilgrimage heritage site and also the role played by Abbot Francis Pfanner in its establishment. Furthermore, the paper discusses the tourism perspective of religious pilgrimage sites. Emmaus heritage site draws visitors from all over the world, and such visitation is linked to religious-travel. A key objective was to unpack an understanding of religious tourism as a driver behind the observance and respect for Emmaus pilgrimage site. A description of the religious tourism perspective is offered as well as the benefits of religious pilgrimages to the destination. The paper is conceptual and emphasis is on the sanctity of the site while also offering some perspective of religious tourism as a strategy to sustain and market the heritage site to attract a greater volume of global pilgrims. A qualitative research method has been used to get answers and a descriptive analysis has been done to show the sanctity of Emmaus heritage site. The paper demonstrates that a 'niche' product of religious tourism is indeed a big drawcard for the industry. There is a 'sanctity' element of Emmaus pilgrimage site as well as a presentation of the key role played by Abbot Francis Pfanner. Reflection of religious tourism and reasons for motivation and promotion of domestic and international pilgrims to visit pilgrimage sites is also briefly considered. In concluding, the paper draws attention to understanding the Roman Catholic religious' traditions such as the pilgrimage.
\end{abstract}

Keywords: Emmaus, Abbot Francis Pfanner; pilgrimage heritage, religious tourism, sustainable strategies

\section{Introduction: Background of Emmaus pilgrimage heritage site}

Abbot Francis Pfanner, was an Austrian Trappist monk who left his Europe to do mission work in Mariannhill Diocese in 1882 near a town called Pinetown close to the city of Durban in KwaZulu-Natal, South Africa. The name was a derivative from those of the Virgin Mary and her mother Saint Anne. The mission in Mariannhill steadily grew to become very successful and was the centre of a great network of mission stations spreading over a vast geographical area. In 1885, Mariannhill created an abbey. In 1898, it became the largest Christian monastery in the world, with 285 monks (Denis, 2014). Abbot Francis Pfanner was elected as the first mitred abbot, this was complimentary to his beliefs, prayers, dedication is service and hard work. It was in 14 October 1890 that he was appointed Vicar General for the Trappist Order for South Africa. In April 1891 Abbot Pfanner went to Rome for the general chapter. On 
account of the distance, he had been authorised to attend only one chapter every five years (Denis, 2014). This explains why, despite abundant reports, the government of the Order knew little about the state of affairs at Mariannhill. During the conference which is labelled as a 'chapter', Abbot Pfanner mentioned the concessions he had made to the rectors of the mission stations, after which the chapter members protested vigorously. To calm their anxiety, the Austrian monk suggested that a visitation should conducted at Mariannhill. Abbot Pfanner was confident that an eyewitness would better understand the motives for his actions (Denis, 2014). Controvertibly and ironically despite his beliefs and hard work, he was blamed for diverting funds to Africa which might have gone to some German monasteries and this was then tabled as an 'unfortunate choice' (Buschgerd, 1990). This was when Abbot Pfanner's relationship inevitably became clouded by prejudice (Denis, 2014).

As could be expected, the visitors sent to review Mariannhill were shocked to see how much Mariannhill had moved away from the Trappist model of monastic life. The Trappist observances were no longer followed faithfully as was expected. The visitors lent an ear to the missionaries who, year after year, had called for greater dispensation from Rome. The avowed purpose of the visitors' reform intention was to break the unlimited power that Francis Pfanner had exercised over his monks which was the common practice, ironically, in full conformity with the rule of St. Benedict from which the Trappist Rule was derived since the foundation of the monastery. The only way of restoring peace in the monastery was to bring down Abbot Francis Pfanner's pride and to drastically reduce his prerogatives. He did not see that by giving more authority to the missionaries he would create the conditions for a further erosion of the observances, the restoration of which was the very purpose of his requested inspection by them.

During the entire length of the visitation, the Abbot was inclined to give 'space' to the 'visitors' who were deployed. Abbot Francis was excluded from all the investigations while the visitors were on site. On finalising the investigation, the visitors went to a mission named Mariathal where Abbot Francis Pfanner was "suspended". He was however a frail and sickly person and this was known to other monks; he was recovering from typhoid. Conclusions of the visitation were finally presented to Abbot Pfanner to obtain his formal consent on them. Apart from restoring the observances, regarding the duration of the novitiate in particular, they insisted on re-establishing the Mission Council with the possibility for the three missionary representatives to outvote the abbot on certain matters and to impose a ban on further expansion, both in terms of acquisition of land and of recruitment of postulants.

Abbot Francis Pfanner prostrated himself at the feet of the visitors, he explained in an autobiographical text, "to do rather too much than too little". This ultimately led to his downfall. The suspension order was accompanied by drastic measures. Francis Pfanner was not allowed to have any contact with the priests, or any of the brothers and sisters of the monastery. He had to refrain from writing and was forbidden from any involvement in temporal affairs. He was informed that should he decide to offer his resignation, he needed to understand that it would not be accepted. He found this measure to be totally unjust, but, when he was confronted with the visitors' carta, he accepted it unconditionally.

The establishment by Abbot Pfanner of numerous sub-stations in the then Natal and the Cape Provinces, brought him into conflict with his superiors because of the mismatch with the rules of the Trappist Order. Pfanner's suspension in 1892 marked the end of his active participation in missionary activities (Khandlhela, 1993). In late January or early February 1893, Abbot Francis Pfanner sent a letter of resignation to the abbot general. Presumably because the suspension order had discouraged him from doing so, he did not send a formal letter of resignation, with the signatures of two witnesses as prescribed in the Rule, but only a "private letter" stating that "under the circumstances, he could no longer govern the "house" referring to the monastery Mariannhill, Francis Pfanner made a brief appearance at Mariannhill to bid farewell to the monks and the sisters. He was told that, as a suspended abbot, he was not allowed to talk to or have any relation with the community at all. 
In April 1894 a permanent place of residence was found for the former abbot; a remote area of two hours' drive from Lourdes by ox-cart. Francis Pfanner gave this place the name of 'Emmaus'. It was there that he spent the last fifteen years of his existence in relative isolation. Emmaus was of course named after the place mentioned in the Gospel of Luke as the village where Jesus appeared to his disciples after his crucifixion and resurrection. Luke 24:13-35 specifies that Jesus appeared after his resurrection to two disciples who were walking from Jerusalem to Emmaus.

Apart from a few sisters nearby and, during the year immediately preceding his death, a fellow monk's presence, Joseph Biegner, the abbot stayed on his own, sharing his time between manual labour, correspondence and reflective prayer. After Abbot Pfanner's death, what he termed as the Religious Missionaries of Marianhill (RMM), became known as the Congregation of Marianhill Missionaries (CMM), with a pure emphasis on missionary efforts and it was no longer obliged to follow the Trappist Rule (Denis, 2014).

\begin{abstract}
At Emmaus, with his abbot's permission, Pfanner's involvement in current affairs resumed almost as before. Between 1894 and 1909, the year of his death, he sent fifty-nine articles to Vergissmeinnicht, twenty-two to Familiare Mitteilungen aus Mariannhillwna a few more to secular newspapers such as The Natal Witness and the Natal Advertiser. He gave numerous advices on church matters, most notably the vexed question of the sisters' canonical status, a problem to which he devoted a considerable amount of energy and for which he received belated recognition. All this shows that Pfanner's time at Emaus can better be described as a retirement than an exile. This being said, the pain of having been unfairly treated remained until the end. (Denis, 2014:
\end{abstract}

Despite the harsh treatment meted out to him, it cannot be denied that Abbot Pfanner's dedication and hard work greatly promoted the work of the Trappist Order in Africa. His efforts promoted local development and led to the opening schools, some clinics, craft workshops, printing presses and even small farms providing work for hundreds of religious workers and others.

\title{
Emmaus today
}

The Emmaus mission is currently enjoying a precious heritage that needs to be acknowledged and kept alive (Gamble, 1984). A religious holiday including Emmaus would be helpful in assisting one finding solitude and be in a better position to determine priorities in life. It has indeed remained a constant inspiration for the Missionaries of Mariannhill (CMM) and of the Precious Blood (CPS), but by far not only for them, but also importantly for the Roman Catholic Church.

Abbot Francis Pfanner's time at Emmaus mission can better be described as a retirement rather than an exile-this being said in relation to the pain of having been unfairly treated which remained the case until the end of his precious dedicated life. The pictures which follow were taken at Emmaus where a pilgrimage is held every year in May in commemoration of his life and sacrifices that made and time he spent before his death at Emmaus Mission.

The missionary approaches of Abbot Franz and his inheritors have over the years become viewed as important initiatives in the spreading of the gospel and in 1906 Pope Pius X approved the Constitutions of the Missionary Sisters of the Precious Blood. The first general chapter of the Congregation took place soon after, and Sr. Paula Emunds was unanimously elected first canonical superior general, to the great delight of the sisters. The missionary spirit of the founder and his early followers had led to the foundation of new mission stations in and around Mariannhill and very soon the Sisters offered service in other countries all over the African continent and also globally (Gamble, 1984).

In 1909, a few months before Pfanner's death, the Holy See, at the petition of the Trappists of Mariannhill, made a considerable change in their status. The Cistercian Rule in its rigour, for 
which Abbot Pfanner was most zealous, was found to be an obstacle to missionary development in some particulars. Hence they were given a milder rule and separated from the Trappist Order by official decree. They became a missionary order in their own right, the Missionary Order of Mariannhill (Denny-Dimitriou, 2010).

At the time of Abbot Franz's death there were at least 55 priests, 223 lay-brothers and 326 nuns working in 42 mission stations among the local population (Welch, 1911).

Mariannhill is basically a collection of suburbs in eThekwini Municipality in KwaZulu Natal, South Africa and the Monastery $16 \mathrm{~km}$ west of Durban making it ai ideal place to visit for religious tourists. Its central location close to the industrial townships of Pinetown and Durban, has allowed Mariannhill to attract people from around the province of KwaZulu Natal who are seeking employment. Consequently, there has been development and growth as several townships were established in Mariannhill such as inter-alia Thornwood, Tshelimnyama, Mariannridge, KwaMamdekazi, and St Wendolins (Marianhill Monastery, 2021).

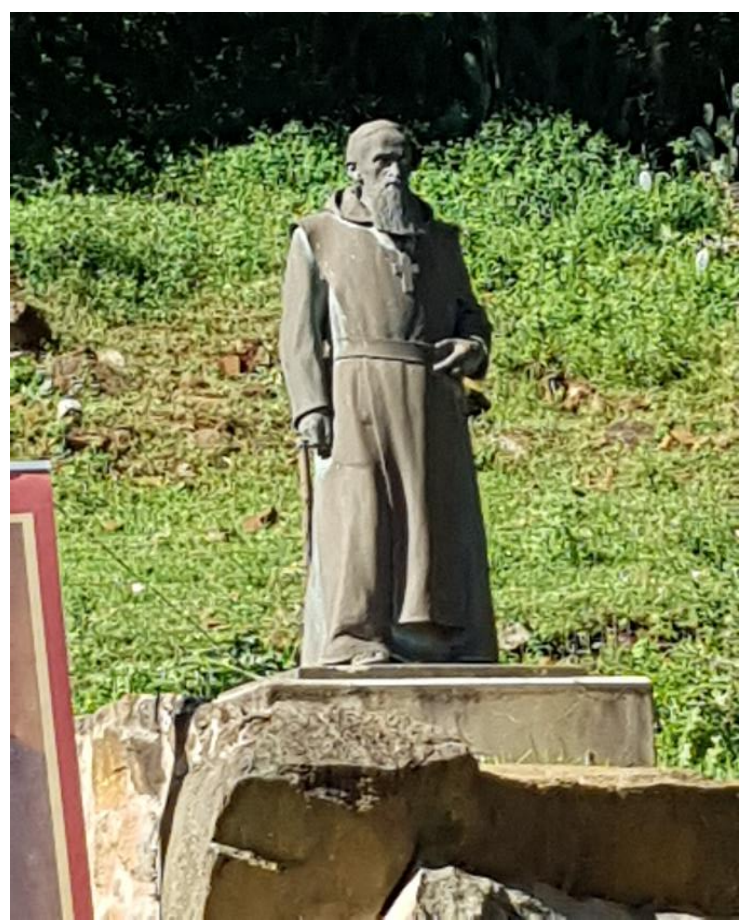

Image 1. Statue of Abbot Francis Pfanner at Emmaus, March, 2021 (Author's own)

Abbot Francis Pfanner dedicated himself to daily praying of the stations of the cross up the hill as self-sacrifice, and in the image below is the monument he built. These pictures portray the architecture and intelligence he had and which he left as legacy to the Roman Catholic Church.

The mission website for Mariannhill states:

Abbot Francis Pfanner is our founder and father of our spiritual and apostolic life. His spirituality has left its mark on our own way of life and has influenced where we are in the world. In 1879 at a request for Trappist monks to go to Africa, Abbot Francis responded, "If no one goes, I will go". As Missionaries of Mariannhill this response poses a constant challenge to our own availability to the promptings of the Holy Spirit and to the mandate entrusted to our Congregation. True to the saying of Abbot Francis that "Our mission field is a part of the kingdom of Christ, and that has no boundaries" as Missionaries of Mariannhill we are in Africa; South Africa, Moçambique, Zimbabwe, Zambia and East Africa; in Europe; Austria, Germany, Switzerland, Netherlands, Italy and Spain; in the United States of America and Canada; in Colombia; Papua New Guinea. (Source: http:// http://cmmmariannhill.org/where-we-are/) 


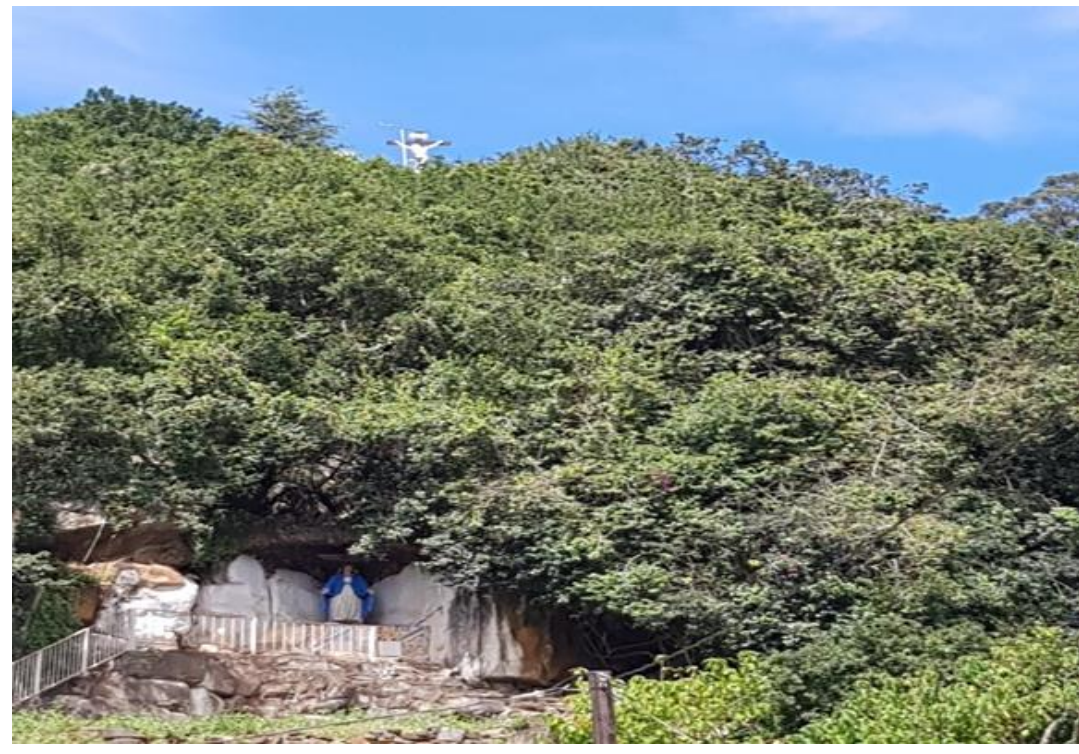

Image 2. Abbot Francis Pfanner's monument. March, 2021 (Author's own)

\section{Understanding of tourism in heritage religious sites}

Tourists visit heritage sites for a variety of reasons (Ho \& McKercher, 2006). They vary from the purposeful tourist who is seeking authentic cultural experiences, to the casual tourist who may be visiting a historic site simply because it is part of their selected tour. Religious pilgrimage tourism is designed to meet the need for spirituality arising out of a highly secular global society and is laden with great personal spiritual and also figurative meanings (Nicolaides, 2016). The paper Towards a pastoral approach to culture (1999) offers several guidelines for the renewal of the cultural and religious heritage within the singularity of religious tourism (Pontifical Council for Culture, 1999). Shrines constitute an important orientation point for cultural tourists, because they offer them the opportunity to experience a slice of the vast cultural heritage of the Christian and other faiths. Religious tourists to Emmaus include also nonbelievers, who are attracted to religious places as elements of cultural heritage.

The significance of a site is often more important to the local community than to tourists. A shrine such as Emmaus promotes communication of faith through culture and thus takes a very important place alongside the anticipated Christian formation.

When an area contains a large number of heritage attractions, tourists tend to visit only the most popular sites. Tourism at religious or sacred sites is a special type of heritage tourism (Shackley, 2001). Many people tend to make an emotional and spiritual investment in a particular place such as Emmaus (Grobler \& Nicolaides, 2017). Preserving heritage at religious sites requires allowing the local community to continue using the site; however, religious practices can be disrupted by the presence of too many tourists. The sheer numbers of tourists at heritage sites often causes physical and social impacts. When there are too many tourists, these places lose their sense of spirituality and they shift from being sacred to secular places.

Preservation of a heritage religious site and its continued use is an important component in the sustainability of cultural values (Nicolaides, 2016; McKercher \& du Cros, 2002). The local community and worshippers have a mixed relationship with the tourists who visit there (Bremer, 2004). Residents often take pride in their culture and religion while tourists sadly tend to disrupt religious practices and increase maintenance problems. 
Tourists often view visits to historic religious sites as opportunities for cultural and educational experiences (Olsen, 2006). Tourist seek for authentic experiences that are tied to a specific historic place, rather than just leisure in a resort that could be anywhere (Macleod, 2006). Interpretation can be used to help provide tourists with experiences, while reducing some of the negative impacts of tourism, for example in Marian tourism to Spain (Coccossis, 2005; Nicolaides, 2016). In today's world, people are on a quest for new experiences that are not only authentic but also exclusive. They generally also seek benefits which include inter-alia, their feelings of anticipation, how they enjoy activities they indulge in while on vacation, fresh experiences. For many religious people, travel to a pilgrimage site may be considered to be an important time since it offers potential for psychological as well as spiritual and physical healing experiences (Grobler \& Nicolaides, 2017). Very often a becomes a place of cultural connection, where people diverse meet and share their religious, cultural and social ideals.

It is important to have interpreters that can help the tourists better appreciate what they are seeing as well as to assist in reducing congestion and overcrowding by making tourists aware of alternative sites to visit; and by explaining appropriate tourist behaviours that minimize impacts on the site and its religious use. In order for religious sites to continuously maintain its sanity and holiness, it is imperative for tourists to be made aware of the history and value that a place holds and the processes of being maintained as a regulation and conduct of behaviour on arrival. For sustainability of religious sites, inappropriate tourist behaviours can be controlled in several ways.

At the Missions, tourists are often not allowed in chapel areas during services so as to reduce conflicts, but this also limits opportunities for participation and education, and may ultimately reduce the experience of the missions of a religious site (Levi, 2002). At the frequently visited religious sites, it is thus a common practice to have guides and monks available to answer questions, and specially selected areas available for tourists who wish to engage in worship oriented activities.

On the other hand, the Missions are more likely to provide written materials and signage with guidelines for visitor behaviour. Heritage sites of religious value in South Africa, could benefit from incorporating the strategies used by their religious counterparts abroad so as to encourage appropriate and desired tourist behaviours. Emmaus heritage site is one of the most visited religious sites at UMzimkhulu; KwaZulu-Natal. Shrines are distinct places of contact between God and man. Typically believers meet there, but also those who are on a spiritual mission. For this reason, the Church for the most part, offers in sanctuaries different kinds of faith communication for believers. Pilgrimage is a common human experience in which one seeks to fulfil a ritual responsibility, accomplish an act of devotion to atone their own sins, live an experience of spirituality, or entreat God for His grace, and obtain a miracle, a cure, etc. The notion of a pilgrimage has an very strong foundation in both the Old and New Testaments and is important in Roman Catholicism.

The life of the apostle Abbot Francis Pfanner is celebrated in the month of May, as this is the time when he died a lonely death after being suspended at Mariannhill. History narrates that during his suspension he was not allowed to meet with his fellow brothers and sisters. As a sacrifice to his unacceptable suspension he built the station of the cross on the hill at Emmaus and he prayed the stations of the cross walking this mountain every day in devotion to the Lord. One goes on a pilgrimage places such as Marrianhill and Emmaus to ask God for help needed to live more generously once back in at home. So a pilgrimage is not, and never should be viewed just some trip to a place of religious interest. Whether one is alone or with others, "... it is a physical component of the path of one's heart toward God" (Lubov, 2021)

Even when he was at his weakest point physically, because of his deteriorating health, Abbot Pfanner kept his faith in God until such time when he died in the hands of the sisters who took care of him. 


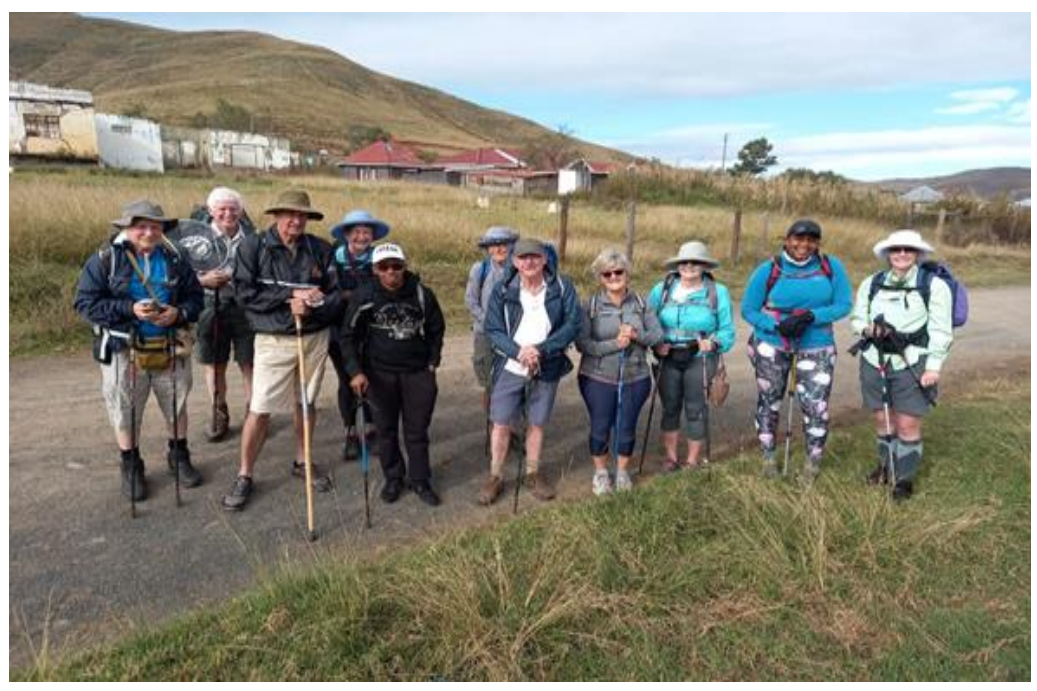

Image 3. Fr. Njivela, a co-author, "On the road to our Emmaus), 2021 (authors own)

Fr. Njiyela on a tour with tourists visiting all the sites that Abbot Francis built and where he left his legacy and stored Christian faith. The image above was during a journey from Lourdes mission to Emmaus mission which was Abbots last destination, where he died in 24 May 1909. The silence and peace in an area, which a tourist or a pilgrim visits such as Emmaus can serve to facilitate their prayer and give them an opportunity for a needed change of heart.

\section{Perspectives of pilgrimage sites}

Reflecting on the meaning of pilgrimage, and its effective management, Di Giovine and Elsner (2015), suggest that tourism professionals must appreciate the multiplicity of heightened meanings, conflicting ideologies, and modes of interaction surrounding pilgrimage sites, which may conflict with the socioeconomic and political norms espoused by the tourism industry and other outside forces. The mission of shrines is to satisfactorily welcome all groups of visitors but first it is necessary to distinguish the needs of the visitors. This recognition determines the forms of evangelization that could result: from simple tools to individual treatment including willingness to listen and spiritual accompaniment. In all cases, Shrines are continuously a place of adoration and meditation (Wiśniewski, 2018). Where religious people such as Abbot Fanner have created some space of interfacing with the divine, tourism can indeed thrive as people seek knowledge and growth in spiritual things (Bremer, 2006).

Managing religious tourism requires a deep understanding of the experience sought, the site itself and the interaction between participant and site (Nkwanyana;2020). Di Giovine and Elsner (2015), classify religious sites, (1) as pilgrimage shrines which are built around tombs of holy people as is the evidence case of Emmaus heritage site. (2) historical sites associated with saints or prophets these are places of apparition and environmental formations or (3) built structures that suggest divine interaction on earth which manifest themselves to pilgrims. In most Roman Catholic places, visitors are encouraged to respect the sanctity of the site; this is done by respectfully bowing and making a sign of a cross and then pausing for reflection, lighting candles and engaging in deep and meaningful spiritual practices.

Visitors basically need to be taught how to treat the sacred space and all people around them at site with respect (Aulet \& Vidal, 2018). Dress must be appropriate to show respect for nature and spirit of a site. The worth of both the tangible and intangible fundamentals of a site visit need to be carefully considered and the expected guest mix also need consideration (CollinsKreiner, 2010). It would be useful to have brochures on the site and well versed guides. 


\section{Classification of pilgrimage sites}

Pilgrimage sites have a range of classifications and some are described in the table which follows below.

\begin{tabular}{|c|c|}
\hline (a) Pilgrim Shrines & $\begin{array}{l}\text { Places that serve as the goal for pilgrim journeys. } \\
\text { These can be: }\end{array}$ \\
\hline (b)Shrines of relatively low value as tourist attractions & $\begin{array}{l}\text { where the majority of visitors are either members } \\
\text { of religious tour groups or consider themselves to } \\
\text { be pilgrims. }\end{array}$ \\
\hline (c) Shrines of high value as tourist attractions & where tourists tend to outnumber pilgrims \\
\hline $\begin{array}{l}\text { (d) Shrines primarily noted for colourful pilgrimage } \\
\text { events }\end{array}$ & $\begin{array}{l}\text { where pilgrimages are usually held on an annual } \\
\text { or biannual basis. }\end{array}$ \\
\hline $\begin{array}{l}\text { (e) Shrines combining touristic importance, pilgrimage } \\
\text { festivals, and cultic significance }\end{array}$ & $\begin{array}{l}\text { which are visited throughout the year by large } \\
\text { numbers of tourists and pilgrims. }\end{array}$ \\
\hline (f) Religious Tourist Attractions & $\begin{array}{l}\text { Places, usually ecclesiastical structures which are } \\
\text { visited by secularly orientated tourists, } \\
\text { recreationists and religious tour groups. They are } \\
\text { not considered to be places of pilgrimage in their } \\
\text { own right and include famous cathedrals and } \\
\text { monastic establishments. }\end{array}$ \\
\hline (g) Sites of Religious Festivals & $\begin{array}{l}\text { Religious festivals and processions which are not } \\
\text { thought of as pilgrimage occasions - including } \\
\text { Holy Week and Corpus Christi processions, } \\
\text { public Christmas or Easter celebrations etc. } \\
\text { These are usually associated with churches, } \\
\text { some of which are important as tourist attractions } \\
\text { and historic monuments in their own right. }\end{array}$ \\
\hline
\end{tabular}

Source: McGettigan, (2003).

\section{Awareness, management and conservation of pilgrimage sites}

The awareness of proper management and conservation of pilgrimage routes, was raised among tourists and residents by the WHO in August (2012). It was stated that a lack of awareness among local people and tourists is one of the key challenge in conserving and managing pilgrimage and religious sites, and UNESCO listing does not always enhance it.

Issues in management and conservation have been man-made. Some have been done without knowing the principles and regulations of managing pilgrimage sites. Jimura (2007, 2011) asserts that conservation and management problems can still be caused by local people if they don't conform to the principles and conduct of behaviour which is listed and made known to the public and tourists. Communities and pilgrimage tourists do not always fully understand the conservation requirements or simply ignore them. Riis and Woodhead, (2010) continue alluding that another cause of management and conservation problems appears to be a lack of the 'sixth sense' and 'amusement, or reverence', which is typically regarded as an essential element of religious devotion to place According to Jimura (2011: 291), "In principle, UNESCO places equal emphasis on the conservation and the use of heritage sites". However, damage caused by excessive visitation and lack of appropriate conservation and management are serious environmental threats for pilgrimage sites (Smith, 2001; Zhang, Fyall \& Zheng, 2015).

Other tourist-induced management concerns are vandalism, crime and litter (Jimura, 2007). In Emmaus, there has been no serious vandalism, crime or litter problems despite an increase in the number of pilgrimage consumers. This was confirmed by the researcher's site visit and observations during a pilgrimage in March 2021. However, irresponsible visitors do cause problems owing to their lack of awareness and understanding of religious sites and the 
meaning of religious pilgrimage sites. For example, some people use the pilgrimage route with no consciousness and knowledge of conservation, thus causing or do things leading to erosion. The major causes of land erosion and degradation are due to the lack of a sense of awareness of conservation as noted before. Jimura $(2007 ; 2011)$ also suggests that issues in management and conservation could also be caused by rapid and extensive tourism development after UNESCO branding. Concerning Emmaus pilgrimage site however, evidence of such issues has not been confirmed in spite of the increased number of pilgrims and visitors annually.

To prevent these problems, a mini-guide containing rules for pilgrimage tourists and other visitors was compiled in 2005 for World Heritage Sites. The rules have been promoted on the Internet and with leaflets.

Amongst the stipulated rules that should be adopted by Emmaus pilgrimage site are that of (1) Conservation and management activities and principles must be displayed at entrance points. (2) The footpath maintenance where stations of the cross used by Abbot Francis during his time and daily living should be kept as holy route. Emmaus pilgrimage site management is emphasising conservation and proper management, this was evident by the documents sold on site and management of the accommodation site and corridors. The site visit and observations during the pilgrimage confirmed that Emmaus station of the cross route was in good condition and resembles 'exactly' the suffering that Abbot Francis chose for himself as a sacrifice and in dealing with his suspension from Mariannhill. However, management and conservation still needs to be improved (e.g. planting of flowers, cutting of grass on the outside of the entrance to keep it clean, constructing of ablutions facilities for use during pilgrimage days. These are examples and plans of managing and conserving the site.

These above examples are echoed by Spencer and Nsiah (2013) who argue that such principles and strategies of conserving and management should be listed to inspire the local community and to assist in managing visitor attractions. This observation demonstrates that Emmaus pilgrimage (mission) site has potential to encourage the participation of the local community in the preservation of what is basically their pilgrimage site. The sustainability of Emmaus pilgrimage site depends chiefly on local communities' attitudes towards support for and understanding of conservation and management activities (Nkwanyana, 2021). Religious tourism is a good source of community empowerment and development since the interest of tourists in local values and communities helps in developing a sense of empowerment and boosts pride in the local community, its culture and rich African history.

\section{Conclusion}

Religious tourism and pilgrimage are substantial motives for the global movement of people, Emmaus being no exception. It matters not whether travelling is for purely gaining experience, leisure, fun or for economic contribution to the destination. Tourism to such sites also includes religious motives and pilgrimages visitation is influenced by some secular desires as well. The description and sanctity of Emmaus heritage site where Abbot Francis Pfanner spent his last days is a journey to be taken for entirely spiritual motives as discussed in this reflection. The priests and nuns do recognise their responsibility for the future development and sustainability of Emmaus mission. Places such as Emmaus are Christian sanctuaries which are places of an often unique contact between man and the Creator. In fact the Catholic Church's Magisterium since the second half of the 20th century has invited numerous shrine rectors to make sacred sites they administer places of the 'New Evangelization' (Wiśniewski, 2018).

The main issue being highlighted in this piece of writing is the sanctity and intensity of religionlinked travel, which sadly goes largely unnoticed for the most part, by domestic, national and international tourism agencies. Cugini (2021) assets that sacred places are also a tool for socioeconomic and cultural development of the destinations they serve. In the past decade, 
looked at globally, 'Religious Tourism' has seen both huge economic and education-sector growth. Religious tourism is undoubtedly one of the earliest forms of tourism and is a rapid growing market that a country like South Africa cannot afford to miss out on. Sacred spaces such as Emmaus serve in a way to lucidly develop the relationship between the community and its religious practices and also make more evident the relationship between the people and God.

\section{References}

Aulet, S. \& Vidal, D. (2018). Tourism and religion: sacred spaces as transmitters of heritage values, Church, Communication and Culture, 3(3), 237-259. DOI: $10.1080 / 23753234.2018 .1542280$

Bremer, T. (2004). Blessed with tourists: The borderlands of religion and tourism in San Antonio. Chapel Hill: University of North Carolina Press.

Bremer, T. S. (2006). "Sacred Spaces and Tourist Places." In Tourism, Religion and Spiritual Journeys, edited by D. J. Timothy and D. H. Olsen, 25-35. London, New York, NY: Routledge.

Buschgerd, A. (1990). For a great price. The story of the Missionary Sisters of the Precious Blood. Reimlingen: Mariannhill Mission Press.

Coccossis, H. (2005). Operational management of cultural and heritage sites. In M. Sigala \& D. Leslie (eds.) International cultural tourism: Management, implications and cases (pp 5364). Amsterdam: Elsevier.

Charoenwongsa, P. (2004). Heritage resource management in tourism. In M. Bradford \& E. Lee (Eds.), Tourism and cultural heritage in Southeast Asia (pp. 41-53). Bangkok: SEAMEOSPAFA.

Chifos, C. (2006). Culture, environment and livelihood: Potential for crafting sustainable communities in Chiang Mai. International Journal of Environment and Sustainable Development, 5(3), 315-332.

Collins-Kreiner, N. (2010). Researching Pilgrimage, Annals of Tourism Research, 37(2), 440 456. doi:10.1016/j.annals.2009.10.016

Cugini, A. (2021), "Religious tourism and Sustainability: From Devotion to Spiritual Experience* ", Grasso, F. and Sergi, B.S. (Ed.) Tourism in the Mediterranean Sea, Emerald Publishing Limited, Bingley, pp. 55-73. https://doi.org/10.1108/978-1-80043-900-920211006

Denis, P. (2013). Mission, civilisation and coercion in colonial Natal. Abbot Frantz Pfanner and the African 'Other' in Mariannhill (1882-1909). Lithuanian Catholic Academy of Science Annuals, 37(6), Studies in Church History.

Denis, P. (2014). The suspension and resignation of Franz Pfanner, first abbot of Mariannhill, School of Religion, Philosophy and Classics, University of KwaZulu-Natal Pietermaritzburg.

Denny-Dimitriou, J, (Nov 23, 2010). "How one monk changed the South African landscape". OSV Newsweekly.

Gamble, H. (1984). Mariannhill: A century of prayer and work, 1882-1982, (Mariannhill, Mariannhill Mission Press, pp.146-154. 
Hall, C. M., \& Piggin, R. (2003). World Heritage sites: managing the brand. In A. Fyall, B. Garrod and A. Leask, (Eds.), Managing Visitor Attractions: New Direction (pp. 203-219). Oxford: Butterworth-Heinemann.

Jimura, T. (2007). The impact of World Heritage Site designation on local communities - a comparative study of Ogimachi (Japan) and Saltaire (UK) (Unpublished doctoral thesis). Nottingham Trent University, Nottingham.

Jimura, T. (2011). The impact of world heritage site designation on local communities - A case study of Ogimachi, Shirakawa-mura, Japan. Tourism Management, 32 (2), 288-296.

Jimura, T. (2015). The relationship between World Heritage Site inscription and local identity. In L. Bourdeau, M. Gravari-Barbas, \& M. Robinson (Eds.), World Heritage, Tourism and Identity: Inscription and Co-production. Farnham: Ashgate.

Khandlhela, R.S. (1993). Mariannhill Mission and African Education, 1882-1915. Thesis submitted in partial fulfilment of the requirements of the degree of Masters of Arts in the Department of History, University of Natal, Durban, 1993

Lubov, D.C. (2021). What is the Point of a Pilgrimage? Simply Catholic. [Available online at https://www.simplycatholic.com/what-is-the-point-of-a-pilgrimage/]

Marianhill Monastery. (2021). Abbot Francis Pfanner Founder of the Mariannhill Monastery, Ora et Labora, Pray and Work. [Available online at http://mariannhillmonastery.org.za/]

Macleod, N. (2006). Cultural tourism: Aspects of authenticity and commodification. In M. Smith \& M. Robinson (eds.) Cultural tourism in a changing world (pp. 177-190). Clevedon: Channel View Publication.

McCarthy, L. (2012). Finding and Closing Faith Based Travellers' presented at Webinar on Faith-based Travel 101, hosted by National Tour Association, USA.

McGettigan, F. (2003). An Analysis of Cultural Tourism and its Relationship with Religious Sites, in Fernandes, C., McGettigan, F., Edwards, J. Religious Tourism and Pilgrimage, Tourism Board of Léria, Fatima.

Mintel, M. (2005). Religious Tourism, Travel \& Tourism Analyst, March 2005, Mintel International Group Ltd: London.

Mintel, M. (2012). Religious and Pilgrimage Tourism - International - February 2012, Mintel International Group Ltd: London.

McKercher, B. \& du Cros, H. (2002). Cultural tourism: The partnership between tourism and cultural heritage management. New York: Haworth Hospitality Press

Nicolaides, A. \& Grobler, A. (2017). Spirituality, Wellness Tourism and Quality of Life, African Journal of Hospitality, Tourism and Leisure, 6(1).

Nicolaides, A. (2016). Marian Tourism: Eastern Orthodox and Roman Catholic pilgrimage, African Journal of Hospitality, Tourism and Leisure, 5(4).

Nkwanyana, S. \& Xulu, D. (2020). Indigenous knowledge incorporating pastoral healing and pilgrimage tourism: The case of Ngome Marian Shrine, Pharos Journal of Theology, Volume 101. 
Raj, R. \& Griffin, K. (Eds.) (2015). Religious Tourism and Pilgrimage Management: An International Perspective, Second Edition, CABI, Wallingford.

Raj, R. \& Griffin, K. (Eds.) (2017). Conflicts, Challenges, Religion and Culture, CABI, Wallingford.

Riis, O. \& Woodhead, L. (2010). A Sociology of Religious Emotion. Oxford: Oxford University Press.

Olsen, D. (2006). Management issues for religious heritage attractions. In D. Timothy \& D. Olsen (Eds.) Tourism, religion and spiritual journeys (pp 104-118). New York: Routledge. Shackley, M. (2001). Managing sacred sites. Padstow, UK: Thomson.

Smith, M. (2002). A Critical Evaluation of the Global Accolade: the significance of World Heritage Site status for Maritime Greenwich. International Journal of Heritage Studies, 8(2), 137-151.

Spencer, D. M. \& Nsiah, C. (2013). The economic consequences of community support for tourism: A case study of a heritage fish hatchery. Tourism Management, 34, 221- 230.

Welch, S. (1911). Franz Pfanner. In The Catholic Encyclopedia. New York: Robert Appleton Company. [Available online at New Advent: http://www.newadvent.org/cathen/11785c.htm]

Wiśniewski, Łukasz (2018). Religious tourism in Christian sanctuaries: the implications of mixed interests for the communication of the faith, Church, Communication and Culture, 3(3), 199-220, DOI: 10.1080/23753234.2018.1537674 